\title{
Arabidopsis brassinosteroid biosynthetic mutant dwarf7-1 exhibits slower rates of cell division and shoot induction
}

\author{
Jinyeong Cheon'1, So-Young Park², Burkhard Schulz ${ }^{3}$, Sunghwa Choe ${ }^{1,4^{*}}$
}

\begin{abstract}
Background: Plant growth depends on both cell division and cell expansion. Plant hormones, including brassinosteroids (BRs), are central to the control of these two cellular processes. Despite clear evidence that BRs regulate cell elongation, their roles in cell division have remained elusive.

Results: Here, we report results emphasizing the importance of BRs in cell division. An Arabidopsis BR biosynthetic mutant, dwarf7-1, displayed various characteristics attributable to slower cell division rates. We found that the DWARF4 gene which encodes for an enzyme catalyzing a rate-determining step in the BR biosynthetic pathways, is highly expressed in the actively dividing callus, suggesting that BR biosynthesis is necessary for dividing cells. Furthermore, dwf7-1 showed noticeably slower rates of callus growth and shoot induction relative to wild-type control. Flow cytometric analyses of the nuclei derived from either calli or intact roots revealed that the cell division index, which was represented as the ratio of cells at the G2/M vs. G1 phases, was smaller in dwf7-1 plants. Finally, we found that the expression levels of the genes involved in cell division and shoot induction, such as PROLIFERATING CELL NUCLEAR ANTIGEN2 (PCNA2) and ENHANCER OF SHOOT REGENERATION2 (ESR2), were also lower in $d w f 7-1$ as compared with wild type.

Conclusions: Taken together, results of callus induction, shoot regeneration, flow cytometry, and semi-quantitative RT-PCR analysis suggest that BRs play important roles in both cell division and cell differentiation in Arabidopsis.
\end{abstract}

\section{Background}

Plant steroidal hormones, brassinosteroids (BRs), are central to supporting the proper growth and development of plants. As a result, BR biosynthetic and response mutants exhibit phenotypes characterized by severe growth deficiencies. Mutants of various species, including Arabidopsis, pea, tomato, rice, barley, and morning glory, have been found and shown to display similar phenotypes of growth deficiency [1-5].

Brassinolide (BL), the most active BR and an end product of the BR biosynthetic pathway in Arabidopsis, is synthesized from sterols, including campesterol or cholesterol [6]. Of the enzymes involved in BR biosynthesis, the C22- $\alpha$-hydroxylase DWARF4 (DWF4) mediates a rate-determining step $[7,8]$. After going through this

\footnotetext{
* Correspondence: shchoe@snu.ac.kr

'School of Biological Sciences, College of Natural Sciences, Seoul National University, Seoul 151-747, Korea

Full list of author information is available at the end of the article
}

step, intermediates possess dramatically increased bioactivities [6]. As such, the enzymatic steps could be classified as enzymes active before and after DWF4. The enzymes DWARF1/DIM1/CBB1 [9], DWARF5 [10], DWARF7 [11], and DE-ETIOLATED2 [12-14] act before DWF4, whereas CONSTITUTIVE PHOTOMORPHOGENESIS AND DWARFISM (CPD) [15,16], ROTUNDAFOLIA3 (ROT3) $[17,18]$, Cytochrome P450 (CYP90D1) [19] and BR6-oxidase (BR6Ox) [20-28] are active after DWF4. Depending on the species and especially in rice, BR biosynthetic pathways culminate at castasterone (CS) which serves as the primary bioactive $\mathrm{BR}$, rather than $\mathrm{BL}$ [20]. The two bioactive BRs in Arabidopsis, CS and BL, are perceived by a plasma membrane-localized receptor complex composed of BRI1 and BAK1 [29-32]. Upon phosphorylation and activation by $\mathrm{BRs}$, the receptor complex dissociates a negative regulator BRI1 KINASE INHIBITOR1 (BKI1) [33]. BRI1 SUPPRESSOR1 (BSU1), which is a protein phosphatase with
C Biomed Central

() 2010 Cheon et al; licensee BioMed Central Ltd. This is an Open Access article distributed under the terms of the Creative Commons Attribution License (http://creativecommons.org/licenses/by/2.0), which permits unrestricted use, distribution, and reproduction in any medium, provided the original work is properly cited. 
a Kelch-repeat domain, is bound by activated BSK1 $[5,34]$ to deactivate the negative regulator BRASSINOSTEROID-INSENSITIVE2 (BIN2) [35-38], diminishing its negative regulatory effects [34].

The transcription of BR-dependent genes is regulated by a plant-specific family of transcription factors including BRASSINAZOL-RESISTANT1 (BZR1) [39] and BRI1-EMS-SUPPRESSOR1 (BES1) $[40,41]$ in Arabidopsis. Although BES1 and BZR1 share $88 \%$ identity at their amino acid sequences, the two transcription factors regulate their target genes differently; BES1 is involved in transcriptional activation [40], and BZR1 both activates and represses transcription $[39,42]$. As such, constitutive BR phenotypes are seen in the bes $1-D$ mutant [40], whereas the semi-dwarf phenotype is a characteristic of the light-grown bzr1-D mutant due to the repression of its target gene, DWF4 [42].

As compared with the roles that BRs play in cell elongation, their effects on cell division have not received as much focus in studies to date. Earlier research suggested that BRs stimulate cell division [43-46], which was based on observations of the effects of BRs on cultures of suspension cells or protoplasts. At the molecular level, it was found that the stimulation of cell division in the BR biosynthetic mutant de-etiolated 2 results from the activation of the $C y c D 3$ gene in Arabidopsis [47]. In addition to the callus or protoplast system, clearer evidence was provided by a recent paper showing that BR-deficient mutants exhibit fewer numbers of cells in the provascular ring of inflorescences, resulting in a reduced number of vascular bundles in these mutants [48].

Using Arabidopsis mutants that are defective in BR biosynthesis, $d w f 7-1$, we investigated the role of BRs in cell division. We examined the differences in the establishment of mutant-derived calli, shoot regeneration from calli or directly from root explants. In addition, we employed flow cytometric analyses to look at cell cycle progression. Finally, the transcript levels of the genes involved in cell division and cell differentiation were tested in wild type and BR mutants. Our results provide evidence that BRs actively regulate cell division in Arabidopsis.

\section{Results and Discussion}

A BR biosynthetic mutant displays differences in callus induction rate

The exogenous application of brassinosteroids was previously shown to simulate cell division during callus culture. To test whether the endogenous alteration of the BR levels affects the callus induction and cell division rates, a mutant defective in BR biosynthesis, $d w f 7-1$, was subjected to callus induction. Figure $1 \mathrm{~A}$ illustrates the seedling phenotypes of the Ws-2 wild type and $d w f 7-1$. As compared with the wild type, $d w f 7-1$ exhibited more

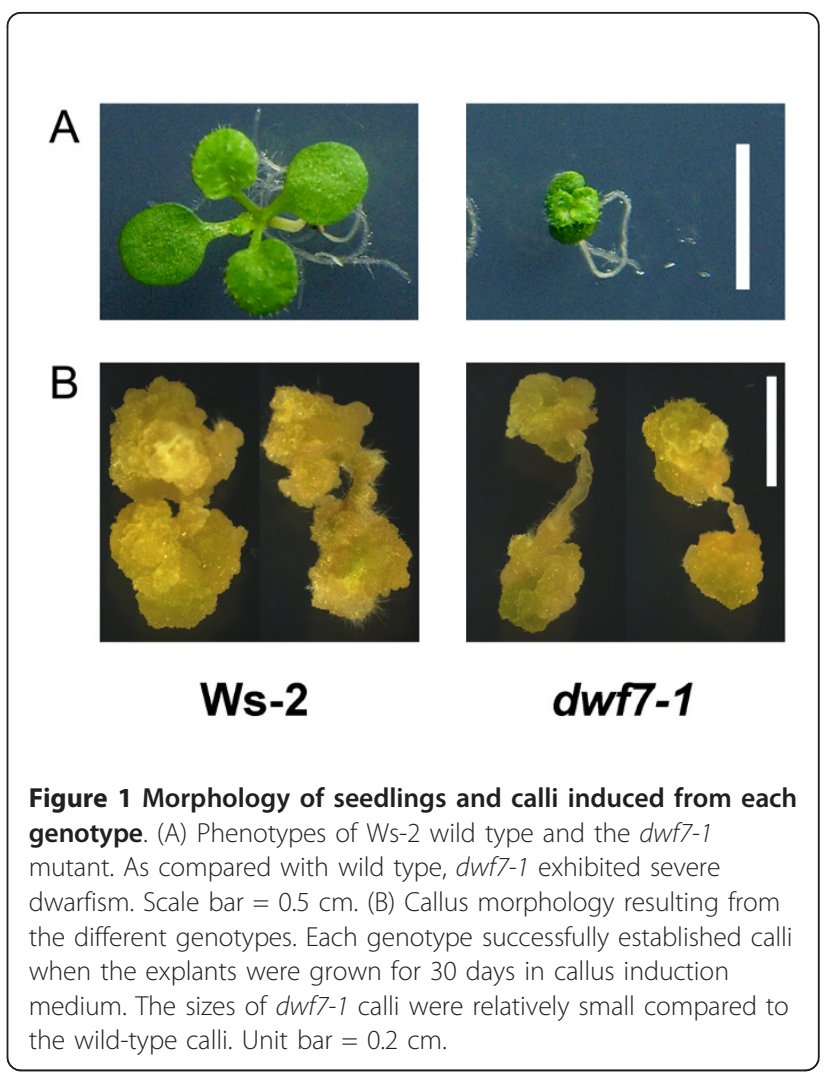

severe dwarfism due to defects in BR biosynthesis. When calli were induced from root explants, BR mutants successfully established visually discernable calli after 15 days. Figure 1B displays the morphology of the representative calli grown for 30 days after the induction from root explants. Noticeably, the size of calli from $d w f 7-1$ is smaller relative to the wild type (Figure $1 \mathrm{~B}$ ).

The slower growth of the mutant could be due to either slower cell division or slower cell growth or both, but in any case, it is obvious that BRs are important to this process.

\section{The BR biosynthetic gene DWARF4 is actively expressed} in calli

To examine whether BRs are required during callus establishment, we checked the expression level of the DWF4 promoter-GUS reporter gene [49]. As part of an important rate-determining step, DWF4 expression was proposed to represent tissues with enriched BR levels [49].

First, in vivo GUS assays revealed that DWF4 is strongly expressed in both wild-type and $d w f 7-1$ calli [42]. This in vivo GUS assay was further visualized by GUS histochemical staining (Figure 2B). The dark blue staining, signifying GUS activity, was prominent in both the wild type and $d w f 7-1$ relative to the control calli that were not stained with GUS (Figure 2B). Because we previously found that exogenously supplied auxin 
The ratios of cells at G2/M vs. G1 phases are low in dwf7-1 Because we observed that BR mutants display different rates of callus induction, we tested whether this is associated with a difference in cell division rates. To do this, we measured the DNA content in the nuclei of each callus using flow cytometry. Figure 3 illustrates the results with a $100 \%$ stacked column chart. The percentage of cells in the three phases of the cell cycle-G1, S, and G2/M-were evaluated by the Partec software.

When cell division indices (ratio of G2M\% vs. G1\%) were compared, the portion of wild-type cells in G1 phase gradually decreased with time, whereas the portion in $\mathrm{S}$ and G2/M phases increased. This suggests that wild-type cells are synthesizing DNA and dividing until the 9th day after transfer to fresh medium. In $d w f 7-1$ cells, both phases remained relatively stable; G2/M at their 30s and G1 at 50s percentage.

The ratios of G2/M vs. G1 were then compared. Wild type increased from 0.3 at day 3 to 1.7 at day 9. However, the ratios were relatively stable in $d w f 7-1$ cells, holding at 0.6-0.7 regardless of time, suggesting that it takes longer for $d w f 7-1$ callus cells to finish one round of cell division.

\section{A BR mutant displays differential level of shoot induction from calli}

We next aimed to test whether a BR deficiency affects the shoot induction rate. Two different routes were

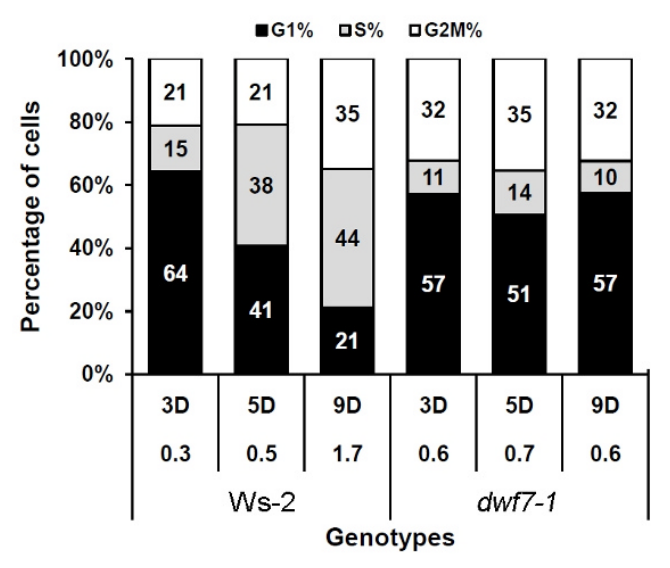

Figure 3 Flow cytometry-based time-course analysis of the DNA profile in the nuclei derived from different genotypes of calli. Nuclei isolated from calli grown for 3, 5, and 9 days after transferring to fresh media were subjected to flow cytometry. Percentage of DNA profile corresponding to G1, S, and G2/M phases are plotted in the stacked column chart. Numbers in the stacked column are percentage of each phase. The numbers below each column indicate G2/M vs. G1 ratios. Shown are triplicate experiments of at least 5,000 nuclei. 
taken; shoots were induced from calli and directly from root explants.

First, the calli established from each genotype were subject to shoot regeneration in shoot induction medium (SIM) with different combinations of auxin and cytokinin concentrations; auxin concentrations of 0.05 , $0.1,0.15$, and $0.25 \mathrm{mg} / \mathrm{L}$ and cytokinin concentrations of $1,3,5$, and $7 \mathrm{mg} / \mathrm{L}$. On each medium of the $16 \mathrm{combi}-$ natorial SIMs, three to nine calli were grown for 4 weeks to establish shoots. One representative was chosen for illustration in the Figure 4A. Overall, wild-type calli produced shoots at broad ranges of auxin and cytokinin concentrations. As visible evidence of shoot induction, the calli turned green and produced elongated inflorescences with leaf structures. $d w f 7-1$ calli displayed only marginal signs of shoot induction; parts of calli turned green, but almost no shoots were produced (Figure $4 \mathrm{~A})$.

To present the results more quantitatively, we transformed the degree of shoot induction into arbitrary numbers ranging from 0 to 2 and displayed them using three dimensional charts (Figure 4B). We assigned the numbers 0,1 , and 2 to calli having no shoots, greening only, and visible shoots, respectively; thus, a number close to 2 meant that most of the calli tested at the specific combination of auxin and cytokinin produced visible shoots, whereas a number closer to 0 indicated that none of the calli formed visible shoots. Of the 16 different concentration combinations, the wild type produced shoots at the broadest ranges (Figure 4B, Ws-2). However, shoot induction was noticeably low in $d w f 7-1$ calli.

Shoots were also directly induced from root explants. Figure $4 \mathrm{C}$ summarizes the results. Wild type displayed vigorous shoot induction; explants produced visibly elongated inflorescences with leaves. In contrast, $d w f 7-1$ calli barely displayed shoot induction; developed calli turned green but made only primordial leaves. The lower rates of shoot induction observed in the mutant suggests that BRs are central to controlling cell differentiation as well as division.

Populations of dividing cells are smaller in the roots of dwf7-1 relative to wild-type cells

To examine cell division in the roots of intact plants, the percentage of cells in the three phases of the cell cycle-G1, S, and G2/M-were evaluated with the Partec software. The results are summarized in Figure 5 . When Ws-2 wild-type and $d w f 7-1$ cells were compared, the ratios of cells in the three phases clearly showed differences; the percentage of cells undergoing DNA synthesis and mitosis greatly decreased from 23 to $13 \%$ for $\mathrm{S}$ phase and from 25 to $19 \%$ for G2/M phase. This coincided with an increase in the proportion of G1 cells by about $15 \%$. The dramatically decreased ratios observed
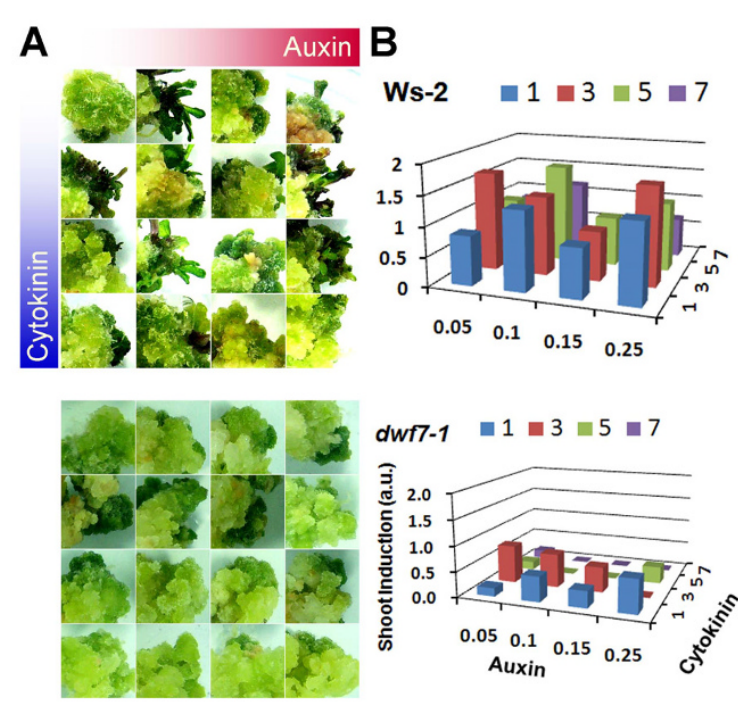

C

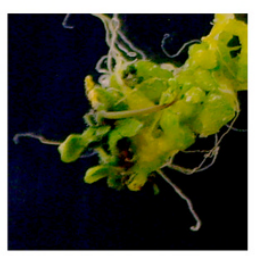

Ws-2

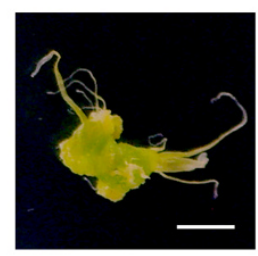

$d w f 7-1$
Figure 4 Organogenesis patterns on a matrix of shoot induction medium. (A) Representative calli grown on each combinatorial medium. The 16 different combinations of IAA $(0.05$, $0.1,0.15$, and $0.25 \mathrm{mg} / \mathrm{L})$ and $\mathrm{N}^{6}$ - $\Delta^{2}$-isopentenyladenine $(1,3,5$, and $7 \mathrm{mg} / \mathrm{L})$ were tested with each callus. 3-9 calli per each concentration were tested. Shown are composite photos of calli arranged after growth on each medium. (B) Degree of shoot induction in specific medium. The labeling for the three axes shown on the dwf7-1 chart is applicable to the Ws-2 graph. Arbitrary unit representing shoot induction rate, ranging from 0 to 2 , was plotted against the combination of auxin and cytokinin. A number close to 2 indicates that each callus tested on the specific medium tended to regenerate shoots successfully. (C) Direct induction of shoots from root explants. Roots were briefly exposed to callus induction media, then transferred to shoot induction media to induce shoots from each genotype. Wild type displays discernable structures of leaves and inflorescences, whereas these morphologies are relatively primordial in dwf7-1 mutant. Scale bar $=0.5 \mathrm{~cm}$.

in the mutant as compared with their parental wild types suggest that cell division is delayed due to decreased BR activities in this mutant.

\section{Genes of BR biosynthesis and cell division show differential expression patterns}

To understand the differences in cell division at the molecular level, we examined the steady state levels of transcripts for the genes involved in BR biosynthesis and cell division. As a control, we included RNA from 


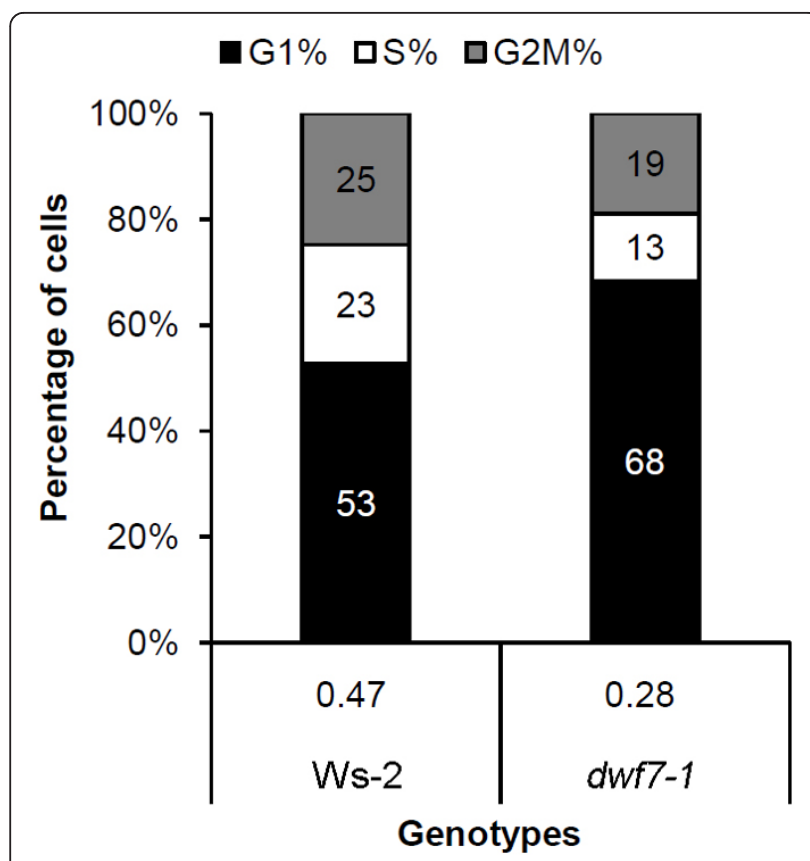

Figure 5 DNA profile in the root cells of $d w f 7-1$ and its parental wild type. Flow cytometry-based DNA profiles in the nuclei derived from roots of different genotypes were determined. Percentage of DNA profile corresponding to G1, S, and G2/M phases are plotted in the stacked column chart. Numbers in the stacked column are percentage of cells in each phase. The numbers below each column indicate ratios of G2/M vs. G1. Shown are triplicates of at least 3,000 nuclei.

whole plants grown for 7 days in the light. Figure 6 shows the results. The expression levels of the two BR biosynthetic genes, DWF4 and BR6OX2, increased in the calli of both $d w f 7-1$ and wild type (Figure 6). This demonstrates that the BR biosynthetic activity is generally upregulated in the callus stage. In contrast, the steady state levels of RbR1, PCNA1, and Cyclin D3;1 $(C y c D 3 ; 1)$ in the two calli stayed unchanged relative to the seedling control.

Previously, it was shown that two genes, ESR2 and ARABIDOPSIS RESPONSE REGULATOR5 (ARR5), are regulated in opposite ways during shoot induction; ESR2 increases but ARR5 decreases [50,51]. We found that ESR2 levels noticeably decreased in $d w f 7-1$ relative to whole seedlings and wild type, whereas ARR5 level stayed high in $d w f 7-1$. Furthermore, a gene that is putatively involved in somatic embryogenesis, SOMATIC EMBRYOGENESIS RELATED KINASE 2 (SERK2), slightly increased in the wild-type callus. In contrast, the level of PCNA2 transcripts representing the status of an active replication of nuclei DNA was significantly low in dwf7-1. The lower levels of both PCNA2 and ESR2 observed in $d w f 7-1$ imply that BRs are required to induce both the two genes, and this might be associated

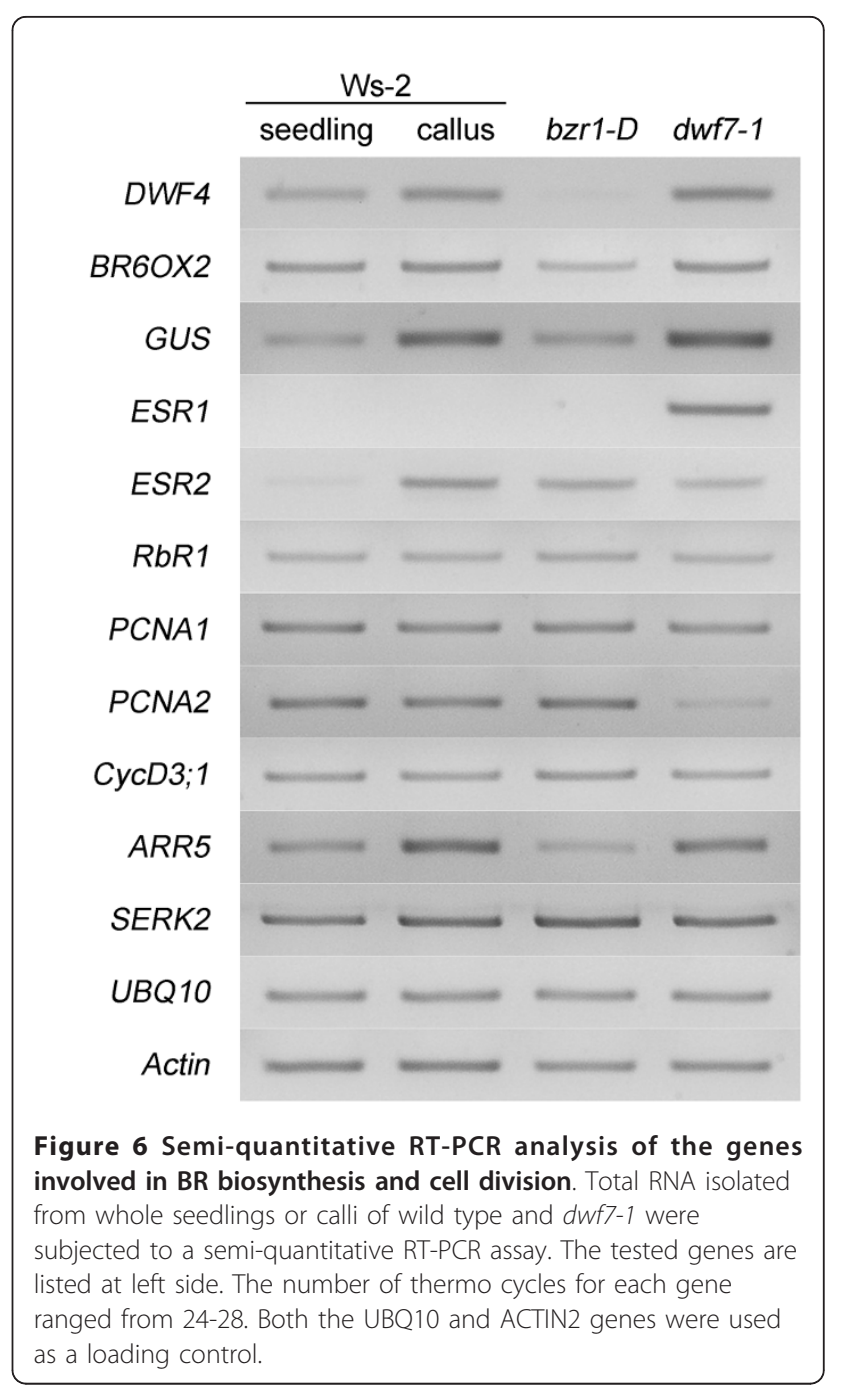

with the lower rate of cell division and shoot induction in the $d w f 7-1$ mutant, as shown in Figure 4.

\section{Conclusions}

We have shown that DWF4 is strongly expressed in dividing callus cells (Figure 2). Previously, we reported that DWF4 was rarely expressed in the limited tissues of intact plants [49] and that its expression led to increased levels of bioactive BRs. The expression of DWF4 in calli suggests that BRs play important roles in supporting the dividing callus cells. In addition, we found that the portion for the number of dividing cells was smaller in the roots of the BR mutant relative to wild type, which clearly indicates that BRs are positive regulators of cell division. Furthermore, we showed that shoot induction rates, which depend on the coordination of cell differentiation processes, were lower in the BR deficient mutant, $d w f 7-1$. Because the expression levels of the ESR2 gene were also lower in $d w f 7-1$ mutant, it is likely that BRs 
take part in controlling shoot induction via regulation of the ESR2 gene. Taken all together, it is evident that BRs control both cell division and differentiation. Future research should work toward developing a detailed mechanism of BR control over sets of genes that are involved in cell division.

\section{Methods}

Plant material, growth conditions, and induction of callus and shoot

Previously, we reported that the promoter-reporter construct DWF4pro:GUS was introduced into various BR mutants by genetic crossing [49]. Here, we used a line that is homozygous for both the reporter gene and a BR mutation: $d w f 7-1$, the biosynthetic mutant. This line and wild-type (Wassilewskija-2, Ws-2) seeds were sterilized and germinated on Murashige and Skoog (MS) media supplemented with $3 \%$ sucrose ( $\mathrm{pH} 5.8$ ). Plants were grown at $22^{\circ} \mathrm{C}$ under long-day conditions ( $16 \mathrm{~h}$ day and $8 \mathrm{~h}$ night).

To induce calli from each genotype, root explants (5 $10 \mathrm{~mm}$ long) were placed on a callus induction medium (CIM) composed of MS salts, $0.5 \mathrm{mg} / \mathrm{L}$ 2,4-dichlorophenoxyacetic acid (2,4-D), and $0.05 \mathrm{mg} / \mathrm{L}$ Kinetin. Calli were induced at $22^{\circ} \mathrm{C}$ under continuous light.

Shoots were induced by growing the calli on media in 16 different combinations of auxin and cytokinin concentrations. Four different concentrations of auxin (IAA) were used, including $0.05,0.1,0.15$, and $0.25 \mathrm{mg}$ $\mathrm{L}^{-1}$, and the cytokinin $\left(\mathrm{N}^{6}-\Delta^{2}\right.$-isopentenyladenine) concentrations used included $1,3,5$, and $7 \mathrm{mg} \mathrm{L}^{-1}$. For each medium with the different auxin and cytokinin concentrations, calli were serially sub-cultured for 6 months, transferred and incubated for 4 weeks until visible shoots formed. This shoot induction was repeated 3 times, and 3-9 calli per each genotype were tested.

The different levels of shoot induction from each genotype were quantified. We converted the degree of shoot induction into an arbitrary numerical representation. If there was visible leaf induction observed in the tested concentration, the callus was assigned the number 2 . When the callus turned green but did not produce a visible shoot, then it was given the number 1 . In addition, as long as there was no sign of shoot induction, it was assigned the number 0 . After converting the callus morphologies to numbers, mean values were obtained. Thus, the number 2 signified that all of the calli tested at the specific combination of auxin and cytokinin concentrations produced visible shoots, whereas the number 0 represented a lack of visible shoot formation from calli.

\section{Flow Cytometry Analysis}

Approximately $30-50 \mathrm{mg}$ of calli grown on callus induction medium was mechanically homogenized using a spatula in $250 \mu \mathrm{l}$ of nuclei extraction buffer (solution A of the High Resolution Kit for Plant DNA, Partec, Munster, Germany). Another $250 \mu \mathrm{l}$ of the nuclei extraction buffer was added, and the calli were further homogenized. After filtration through a $30-\mu \mathrm{m}$ nylon sieve, $1 \mathrm{ml}$ of staining solution containing the dye 4,6-diamidino-2phenylindole- $2 \mathrm{HCl}$ (solution $\mathrm{B}$ of the Kit) was added. DNA profiles were examined using a PAS flow cytometer (Partec), and the acquired data were processed using the FlooMax software (Partec), according to the supplier's protocols. For each sample, a minimum of 5,000 and a maximum of 15,000 particles were examined. To determine the standard peak positions of $2 \mathrm{C}$ and $4 \mathrm{C}$ cells, cotyledons of Arabidopsis seedlings grown for 8 days under the long-day conditions (16:8, light: dark) from which the calli originated were analyzed at least three times.

For flow cytometry of the seedling roots, three roots from 16-day-old seedlings were cut and measured. This was repeated at least 5 times for each genotype. Approximately 3000 particles were examined per reading.

\section{GUS histochemical analysis}

A histochemical analysis of GUS expression was carried out for the detection of DWF4pro:GUS activity. Calli grown for 2 months on CIM were immersed into GUS staining solution $(0.1 \mathrm{M}$ sodium phosphate, $\mathrm{pH}$ 7.0; $10 \mathrm{mM}$ EDTA; $0.5 \mathrm{mM}$ potassium ferricyanide; $0.5 \mathrm{mM}$ potassium ferrocyanide; $0.1 \%$ Triton $\mathrm{X}-100$ ) and incubated for one hour at $37^{\circ} \mathrm{C}$ in darkness. The samples were serially de-stained with ethanol (50\%, 70\%, 90\%, $100 \%$; 30 min each). Callus staining patterns were examined under a stereomicroscope and photographed using a digital camera.

\section{In vivo GUS assay}

Each callus weighing about $35 \mathrm{mg}$ was placed into a well of a 96-well plate, and a substrate solution containing $50 \mathrm{mM}$ sodium phosphate ( $\mathrm{pH}$ 7),10 mM $\beta$-mercaptoethanol, $10 \mathrm{mM}$ EDTA, $0.1 \%[\mathrm{w} / \mathrm{v}]$ SDS, $0.1 \%[\mathrm{w} / \mathrm{v}]$ Triton X-100, 2\% isopropanol; and $440 \mathrm{mg} / \mathrm{l}$ 4-methylumbelliferyl $\beta$-D-glucuronide was added. The plates were incubated for $16 \mathrm{~h}$ at $37^{\circ} \mathrm{C}$ in the dark. To stop the reaction, $100 \mu \mathrm{l}$ of ice cold $0.2 \mathrm{M} \mathrm{Na}_{2} \mathrm{CO}_{3}$ was added. The fluorescence intensity was measured using a spectrophotometer (Varian) with an excitation wavelength of $360 \mathrm{~nm}$ and an emission wavelength of $465 \mathrm{~nm}$. To determine the relative activity of the GUS enzyme, a standard curve was constructed using different concentrations of 4-MU (4-methylumbelliferyl $\beta$-D-glucuronide). The in vivo GUS activity from each genotype was obtained, and mean values were calculated to show standard error $(\mathrm{n}<9)$. 


\section{Semi-quantitative RT-PCR analysis}

Approximately $80 \mathrm{mg}$ of sub-cultured calli from the CIM were ground under liquid nitrogen to a fine powder before transfer to an RNA extraction buffer containing TRIzol (Takara). Total RNA was further purified with chloroform and precipitated with isopropyl alcohol. cDNA synthesis was performed using a reverse transcriptase (Fermentas) and $2 \mu \mathrm{g}$ of total RNA. Each template RNA was normalized using the Ubiquitin10 gene as a loading control. Oligonucleotide sequences used in this analysis are listed in additional file 2. The numbers of cycles used for DNA amplification were 17 for $U B Q 10 ; 24$ for PCNA2, RbR1, and CycD3;1; 25 for DWF4 and BR6Ox2; and 28 for PCNA1.

\section{Additional material}

Additional file 1: GUS staining pattern after auxin washing. Because it was proposed that auxin affects BR responses, we examined the calli after washing off the auxin that had been added to the callus induction medium (CIM).The washed calli also displayed a similar pattern (top row) as those without auxin removal (bottom row). The similar staining pattern with or without auxin washing imply that DWF4 transcription is required for supporting the growth of calli.

Additional file 2: Oligonucleotide sequences used for semiquantitative RT-PCR analysis. The primer sequences are shown with respective locus ID and a melting temperature used in our PCR experiments.

\section{Acknowledgements}

We thank Brian Dilkes for his critical reading of the manuscript. This research was supported in part by grants from the BK21 Research Fellowships funded by the Ministry of Education, Science, and Technology of the Korean Government and Lotte Scholarship Foundation Fellowship (to JNC), the Basic Science Research Program through the National Research Foundation of Korea (NRF) as funded by the Ministry of Education, Science and Technology (2010-0012736), and by Technology Development Program (110033-5) for Agriculture and Forestry, Ministry for Food, Agriculture, Forestry and Fisheries, Republic of Korea. S.D.G.

\section{Author details}

'School of Biological Sciences, College of Natural Sciences, Seoul National University, Seoul 151-747, Korea. ${ }^{2}$ Biotechnology Division, Korea Forest Research Institute, Kwonseon-Gu, Gyeonggi-Do, Suwon 441-350, Korea. ${ }^{3}$ Department of Horticulture and Landscape Architecture, Purdue University, West Lafayette, IN 47907, USA. ${ }^{4}$ Plant Genomics and Breeding Institute, Seoul National University, Seoul 151-921, Korea.

\section{Authors' contributions}

JC performed the experiments. JC and SYP carried out the flow cytometry experiments. BS analyzed the results and revised the manuscript. SC was the principal investigator of the project; he designed and analyzed the experiments and wrote the manuscript. All authors have read and approved the final manuscript.

Received: 24 September 2010 Accepted: 9 December 2010 Published: 9 December 2010

\section{References}

1. Bishop GJ: Brassinosteroid Mutants of Crops. J Plant Growth Regul 2003, 22(4):325-335.

2. Choe S: Brassinosteroid biosynthesis and metabolism. In Plant Hormones: Biosynthesis, Signal transduction, Action!. Edited by: Davies PJ. Dordrecht: Kluwer Academic Publishers; 2004:156-178.
3. Chono M, Honda I, Zeniya H, Yoneyama K, Saisho D, Takeda K, Takatsuto S, Hoshino T, Watanabe Y: A semidwarf phenotype of barley uzu results from a nucleotide substitution in the gene encoding a putative brassinosteroid receptor. Plant Physiol 2003, 133(3):1209-1219.

4. Suzuki Y, Saso K, Fujioka S, Yoshida S, Nitasaka E, Nagata S, Nagasawa H, Takatsuto S, Yamaguchi I: A dwarf mutant strain of Pharbitis nil, Uzukobito (kobito), has defective brassinosteroid biosynthesis. Plant $J$ 2003, 36(3):401-410.

5. Vert G, Nemhauser J, Geldner N, Hong F, Chory J: Molecular mechanisms of steroid hormone signaling in plants. Annu Rev Cell Dev Biol 2005, 21:177-201.

6. Fujioka S, Yokota T: Biosynthesis and metabolism of brassinosteroids. Annu Rev Plant Biol 2003, 54:137-164.

7. Choe S, Dilkes BP, Fujioka S, Takatsuto S, Sakurai A, Feldmann KA: The DWF4 gene of Arabidopsis encodes a cytochrome P450 that mediates multiple 22a-hydroxylation steps in brassinosteroid biosynthesis. Plant Cell 1998, 10(2):231-243.

8. Choe S, Fujioka S, Noguchi T, Takatsuto S, Yoshida S, Feldmann KA: Overexpression of DWARF4 in the brassinosteroid biosynthetic pathway results in increased vegetative growth and seed yield in Arabidopsis. Plant J 2001, 26(6):573-582.

9. Choe S, Dilkes BP, Gregory BD, Ross AS, Yuan H, Noguchi T, Fujioka S, Takatsuto S, Tanaka A, Yoshida S, et al: The Arabidopsis dwarf1 mutant is defective in the conversion of 24-methylenecholesterol to campesterol in brassinosteroid biosynthesis. Plant Physiol 1999, 119(3):897-907.

10. Choe S, Tanaka A, Noguchi T, Fujioka S, Takatsuto S, Ross AS, Tax FE, Yoshida S, Feldmann KA: Lesions in the sterol $\Delta^{7}$ reductase gene of Arabidopsis cause dwarfism due to a block in brassinosteroid biosynthesis. Plant J 2000, 21(5):431-443.

11. Choe S, Noguchi T, Fujioka S, Takatsuto S, Tissier CP, Gregory BD, Ross AS, Tanaka A, Yoshida S, Tax FE, et al: The Arabidopsis dwf7/ste1 mutant is defective in the delta7 sterol C-5 desaturation step leading to brassinosteroid biosynthesis. Plant Cell 1999, 11(2):207-221.

12. Fujioka S, Li J, Choi YH, Seto H, Takatsuto S, Noguchi T, Watanabe T, Kuriyama H, Yokota T, Chory J, et al: The Arabidopsis deetiolated2 mutant is blocked early in brassinosteroid biosynthesis. Plant Cell 1997 9(11):1951-1962.

13. Li J, Biswas MG, Chao A, Russell DW, Chory J: Conservation of function between mammalian and plant steroid 5alpha-reductases. Proc Natl Acad Sci USA 1997, 94(8):3554-3559.

14. Li J, Nagpal P, Vitart V, MCMorris TC, Chory J: A role for brassinosteroids in light-dependent development of Arabidopsis. Science 1996, 272(5260):398-401.

15. Mathur J, Molnar G, Fujioka S, Takatsuto S, Sakurai A, Yokota T, Adam G, Voigt B, Nagy F, Maas C, et al: Transcription of the Arabidopsis CPD gene, encoding a steroidogenic cytochrome P450, is negatively controlled by brassinosteroids. Plant J 1998, 14(5):593-602.

16. Szekeres M, Nemeth K, Koncz-Kalman Z, Mathur J, Kauschmann A, Altmann T, Redei GP, Nagy F, Schell J, Koncz C: Brassinosteroids rescue the deficiency of CYP90, a cytochrome P450, controlling cell elongation and de-etiolation in Arabidopsis. Cell 1996, 85(2):171-182.

17. Kim GT, Fujioka S, Kozuka T, Tax FE, Takatsuto S, Yoshida S, Tsukaya H: CYP90C1 and CYP90D1 are involved in different steps in the brassinosteroid biosynthesis pathway in Arabidopsis thaliana. Plant $J$ 2005, 41(5):710-721.

18. Kim GT, Tsukaya $H$, Uchimiya $H$ : The ROTUNDIFOLIA3 gene of Arabidopsis thaliana encodes a new member of the cytochrome P-450 family that is required for the regulated polar elongation of leaf cells. Genes Dev 1998, 12(15):2381-2391.

19. Ohnishi T, Szatmari AM, Watanabe B, Fujita S, Bancos S, Koncz C, Lafos M, Shibata K, Yokota T, Sakata K, et al: C-23 hydroxylation by Arabidopsis CYP90C1 and CYP90D1 reveals a novel shortcut in brassinosteroid biosynthesis. Plant Cell 2006, 18(11):3275-3288.

20. Kim BK, Fujioka S, Takatsuto S, Tsujimoto M, Choe S: Castasterone is a likely end product of brassinosteroid biosynthetic pathway in rice. Biochem Biophys Res Commun 2008, 374(4):614-619.

21. Bishop GJ, Harrison K, Jones JD: The tomato Dwarf gene isolated by heterologous transposon tagging encodes the first member of a new cytochrome P450 family. Plant Cell 1996, 8(6):959-969.

22. Bishop GJ, Nomura T, Yokota T, Harrison K, Noguchi T, Fujioka S, Takatsuto S, Jones JD, Kamiya Y: The tomato DWARF enzyme catalyses 
C-6 oxidation in brassinosteroid biosynthesis. Proc Natl Acad Sci USA 1999, 96(4):1761-1766.

23. Castle J, Szekeres M, Jenkins G, Bishop GJ: Unique and overlapping expression patterns of Arabidopsis CYP85 genes involved in brassinosteroid C-6 oxidation. Plant Mol Biol 2005, 57(1):129-140.

24. Nomura T, Kushiro T, Yokota T, Kamiya Y, Bishop GJ, Yamaguchi S: The last reaction producing brassinolide is catalyzed by cytochrome P-450s, CYP85A3 in tomato and CYP85A2 in Arabidopsis. J Biol Chem 2005, 280(18):17873-17879.

25. Mori M, Nomura T, Ooka H, Ishizaka M, Yokota T, Sugimoto K, Okabe K, Kajiwara H, Satoh K, Yamamoto K, et al: Isolation and characterization of a rice dwarf mutant with a defect in brassinosteroid biosynthesis. Plant Physiol 2002, 130(3):1152-1161.

26. Shimada Y, Fujioka S, Miyauchi N, Kushiro M, Takatsuto S, Nomura T, Yokota T, Kamiya Y, Bishop GJ, Yoshida S: Brassinosteroid-6-oxidases from Arabidopsis and tomato catalyze multiple C-6 oxidations in brassinosteroid biosynthesis. Plant Physiol 2001, 126(2):770-779.

27. Shimada Y, Goda H, Nakamura A, Takatsuto S, Fujioka S, Yoshida S: Organspecific expression of brassinosteroid-biosynthetic genes and distribution of endogenous brassinosteroids in Arabidopsis. Plant Physiol 2003, 131(1):287-297.

28. Tanaka K, Asami T, Yoshida S, Nakamura Y, Matsuo T, Okamoto S: Brassinosteroid homeostasis in Arabidopsis is ensured by feedback expressions of multiple genes involved in its metabolism. Plant Physiol 2005, 138(2):1117-1125.

29. Clouse SD, Langford M, McMorris TC: A brassinosteroid-insensitive mutant in Arabidopsis thaliana exhibits multiple defects in growth and development. Plant Physiol 1996, 111(3):671-678.

30. Li J, Chory J: A putative leucine-rich repeat receptor kinase involved in brassinosteroid signal transduction. Cell 1997, 90(5):929-938.

31. Wang ZY, Seto H, Fujioka S, Yoshida S, Chory J: BRI1 is a critical component of a plasma-membrane receptor for plant steroids. Nature 2001, 410(6826):380-383.

32. Kinoshita T, Cano-Delgado A, Seto H, Hiranuma S, Fujioka S, Yoshida S, Chory J: Binding of brassinosteroids to the extracellular domain of plant receptor kinase BRI1. Nature 2005, 433(7022):167-171.

33. Wang $X$, Chory J: Brassinosteroids regulate dissociation of BKI1, a negative regulator of BRI1 signaling, from the plasma membrane. Science 2006, 313(5790):1118-1122.

34. Kim TW, Guan S, Sun Y, Deng Z, Tang W, Shang JX, Burlingame AL, Wang ZY: Brassinosteroid signal transduction from cell-surface receptor kinases to nuclear transcription factors. Nat Cell Biol 2009, 11(10):1254-1260.

35. Choe S, Schmitz RJ, Fujioka S, Takatsuto S, Lee MO, Yoshida S, Feldmann KA, Tax FE: Arabidopsis brassinosteroid-insensitive dwarf12 mutants are semidominant and defective in a glycogen synthase kinase 3ß-like kinase. Plant Physiol 2002, 130(3):1506-1515.

36. Li J, Nam KH: Regulation of brassinosteroid signaling by a GSK3/ SHAGGY-like kinase. Science 2002, 295(5558):1299-1301.

37. Peng P, Yan Z, Zhu Y, Li J: Regulation of the Arabidopsis GSK3-like Kinase BRASSINOSTEROID-INSENSITIVE 2 through Proteasome-Mediated Protein Degradation. Mol Plant 2008, 1(2):338-346.

38. Perez-Perez JM, Ponce MR, Micol JL: The ULTRACURVATA2 gene of Arabidopsis encodes an FK506-binding protein involved in auxin and brassinosteroid signaling. Plant Physiol 2004, 134(1):101-117.

39. Wang ZY, Nakano T, Gendron J, He J, Chen M, Vafeados D, Yang $Y$, Fujioka S, Yoshida S, Asami T, et al: Nuclear-localized BZR1 mediates brassinosteroid-induced growth and feedback suppression of brassinosteroid biosynthesis. Dev Cell 2002, 2(4):505-513.

40. Yin Y, Vafeados D, Tao Y, Yoshida S, Asami T, Chory J: A new class of transcription factors mediates brassinosteroid-regulated gene expression in Arabidopsis. Cell 2005, 120(2):249-259.

41. Yin Y, Wang ZY, Mora-Garcia S, Li J, Yoshida S, Asami T, Chory J: BES1 accumulates in the nucleus in response to brassinosteroids to regulate gene expression and promote stem elongation. Cell 2002, 109(2):181-191.

42. He JX, Gendron JM, Sun Y, Gampala SS, Gendron N, Sun CQ, Wang ZY: BZR1 is a transcriptional repressor with dual roles in brassinosteroid homeostasis and growth responses. Science 2005, 307(5715):1634-1638.

43. Mandava NB: Plant Growth-Promoting Brassinosteroids. Ann Rev Plant Physiol 1988, 39:23-52.
44. Willemse J, Kulikova O, de Jong H, Bisseling T: A new whole-mount DNA quantification method and the analysis of nuclear DNA content in the stem-cell niche of Arabidopsis roots. Plant J 2008, 55(5):886-894.

45. Francis D: The plant cell cycle-15 years on. New Phytol 2007, 174(2):261-278.

46. Yoo MJ, Albert VA, Soltis PS, Soltis DE: Phylogenetic diversification of glycogen synthase kinase 3/SHAGGY-like kinase genes in plants. BMC Plant Biol 2006, 6:3.

47. Hu Y, Bao F, Li J: Promotive effect of brassinosteroids on cell division involves a distinct CycD3-induction pathway in Arabidopsis. Plant J 2000, 24(5):693-701.

48. Ibanes M, Fabregas N, Chory J, Cano-Delgado Al: Brassinosteroid signaling and auxin transport are required to establish the periodic pattern of Arabidopsis shoot vascular bundles. Proc Natl Acad Sci USA 2009, 106(32):13630-13635

49. Kim HB, Kwon M, Ryu H, Fujioka S, Takatsuto S, Yoshida S, An CS, Lee I, Hwang I, Choe S: The regulation of DWARF4 expression is likely a critical mechanism in maintaining the homeostasis of bioactive brassinosteroids in Arabidopsis. Plant Physiol 2006, 140(2):548-557.

50. Banno H, Ikeda Y, Niu QW, Chua NH: Overexpression of Arabidopsis ESR1 induces initiation of shoot regeneration. Plant Cell 2001, 13(12):2609-2618.

51. Ikeda Y, Banno H, Niu QW, Howell SH, Chua NH: The ENHANCER OF SHOOT REGENERATION 2 gene in Arabidopsis regulates CUP-SHAPED COTYLEDON 1 at the transcriptional level and controls cotyledon development. Plant Cell Physiol 2006, 47(11):1443-1456.

doi:10.1186/1471-2229-10-270

Cite this article as: Cheon et al: Arabidopsis brassinosteroid biosynthetic mutant $d$ warf7-1 exhibits slower rates of cell division and shoot induction. BMC Plant Biology 2010 10:270.

\section{Submit your next manuscript to BioMed Central and take full advantage of:}

- Convenient online submission

- Thorough peer review

- No space constraints or color figure charges

- Immediate publication on acceptance

- Inclusion in PubMed, CAS, Scopus and Google Scholar

- Research which is freely available for redistribution

Submit your manuscript at www.biomedcentral.com/submit
Ciomed Central 